\title{
Does the New Basel Accord Affect Credit in Italy?
}

\author{
Mario Mustilli, Eugenio D’Angelo, Francesco Campanella, Domenico Graziano \\ Department of Legal and Economic Science, Università Telematica Pegaso, Naples, Italy \\ Email: eugenio.dangelo@unipegaso.it
}

How to cite this paper: Mustilli, M., D'Angelo, E., Campanella, F. and Graziano, D. (2017) Does the New Basel Accord Affect Credit in Italy? American Journal of Industrial and Business Management, 7, 341-351. https://doi.org/10.4236/ajibm.2017.74024

Received: February 11, 2017

Accepted: March 28, 2017

Published: March 31, 2017

Copyright $\odot 2017$ by authors and Scientific Research Publishing Inc. This work is licensed under the Creative Commons Attribution International License (CC BY 4.0).

http://creativecommons.org/licenses/by/4.0/ (c) (i) Open Access

\begin{abstract}
The purpose of this study is to investigate the effect of the Basel regulation on the amount of credit in Italy. The research sample is composed by 343 Italian banks that operated in Europe in 2014. Data were gathered from Bank scope (Bureau Van Dijk database), from Data Stream (Thomson Reuters) and from the annual reports of banks under investigation. After having investigated the relationship between variables, using the Pearson correlation analysis, the research hypotheses have been investigated using the regression analysis (OLS). The research shows that, in Italy, the increase in regulatory capital required by Basel III agreements and the default probability level of client portfolios of the banks would have a major role in the recent contraction of credit. A more efficient solution to reduce the current state of the credit crunch and at the same time increase the solidity of the banking system, could be represented by an intervention in the system of evaluation of creditworthiness and the relationship between banks and enterprises. Such new regulation should reduce the high probability of default (PD) of client portfolios, which seems to be more critical than market risk and operational risk in limiting the amount of credit.
\end{abstract}

\section{Keywords}

Credit Crunch, Basel Accord, Italian Credit Market

\section{Introduction}

The Basel III agreement was conceived in response to the low capitalization and the illiquidity of the banking system that occurred during the crisis of 2007.

Compared with the agreements on credit provided by Basel II, the Basel III agreement introduced new and more severe capital ratios in order to ensure the stability of the banking system and, therefore, to immunize the real economy from the systemic risks related to the possibility of contagion between banks. 
The mechanism by which the Basel III agreements intended to achieve these objectives is essentially due to mandatory provisions on quality, quantity and transparency of the capital base, on the degree of leverage and on the liquidity of the banking system. With regard to the capital requirement (consisting of common equity Tier 1 , additional Tier 1 and Tier 2 ) rules were established to strengthen the minimum requirements by defining detailed threshold values for each of the mentioned equity component. The common equity Tier 1 (ordinary shares and retained earnings) has to be at least equal to $4.5 \%$ of risk-weighted assets. The Tier I capital (consisting of common equity Tier 1 and additional Tier 1) should never be less than $6 \%$ of the risk weighted assets (where the additional Tier 1 will consist of instruments issued by the bank that meet the criteria of computability of additional Tier 1 and not included in Common Equity Tier 1, from the share premium arising from instruments included in additional Tier 1; from instruments issued by consolidated subsidiaries of the bank and held by third parties that meet the criteria of computability in additional Tier 1 and not included in Common Equity Tier 1, from regulatory adjustments applied in the calculation of additional Tier 1).

Furthermore, the total regulatory capital shall not be less than $8 \%$ of the riskweighted assets. Where the Tier 2 capital will consist of instruments issued by the bank that meet the criteria of computability in the supplementary capital (and not included in Tier I capital); by share premium arising from the tools included in the supplementary capital; by instruments issued by consolidated subsidiaries of the bank and held by third parties that meet the criteria of computability in the supplementary capital and not included in the core capital; by certain provisions for credit losses and regulatory adjustments applied in the calculation of supplementary capital. In addition it was introduced an additional capital conservation buffer of the common equity Tier 1 equivalent to $2.5 \%$ of risk weighted assets that banks will have to set aside, in the absence of periods of financial stress, in order to achieve a threshold value equal to $7 \%$ of risk-weighted assets. Finally, another element introduced to strengthen capital requirements is the countercyclical buffer. This buffer, equal to a maximum value of $2.5 \%$, will be due in case of a credit growth that might generate a high systemic risk.

From the perspective of financial leverage, recognized as one of the main drivers of the crisis of the banking system, the Basel III accords have produced an indicator (leverage ratio) in order to ensure monitoring and to restrain the net debt on the balance sheet and off from it. The leverage ratio proposed by the Basel III Accords is the ratio between equity and exposure and has to beat least equal to $3 \%$.

In order to measure liquidity, the Basel Accord introduced two indicators, Liquidity Coverage Ratio and Net Stable Funding Ratio, in order to face possible situations of financial stress for banks.

The Liquidity cover ratio is an indicator that measures the short-term liquidity introduced to ensure that banks hold a sufficient amount of high-quality liquid assets to balance unexpected outflow in case of high cash stress periods (30 
days). The net stable funding ratio aims instead to ensure that the banks have, over a longer time horizon (one year), a stable funding compared to the liquidity of its assets [1].

Therefore, it is possible to argue that the Basel III agreement has the purpose of ensuring financial stability through adequate levels of bank liquidity. However, this regulation seems not to encourage the profitability of banks and, at the same time, it fosters an excessively risk aversion. New lending requirements are so difficult to achieve that may discourage the credit intermediation activities which should, normally, represent the core business of financial intermediaries.

In Italy, the prolongation of the economic crisis and the consequent progressive deterioration of loans in the portfolios of banks (Non Performing Loans), accentuates the mentioned negative effects of Basel III, limiting the credit allocation even to the most eligible companies.

In this context, we must remember that creditworthiness, market risk and operational risk of banks are still evaluated through the use of the models proposed by the Basel II and, at least in Italy, there is no empirical evidence that unequivocally demonstrate the effects of these evaluation systems on credit provided by banks.

Therefore, this study, focusing on credit supply, is designed to demonstrate that, in Italy, the models proposed by the agreements of Basel II and Basel III could contribute to accentuate the credit crunch. The natural consequence of this mechanism will be, on one hand, the perpetuation of the financial crisis of businesses, especially smaller ones, and, on the other, the contraction of income and profitability of the banking system, which would lead to the inevitable strategic turnaround of lenders. Indeed, the Basel mechanisms, to ensure the stability of the banking sector, will push the financial intermediaries not only to provide less credit, with the obvious consequence of lower trading volumes, but also to allocate it only to less risky borrowers, as also advocated by Stiglitz and Weiss [2], hence the decline also banks marginality.

A more efficient solution to reduce the current state of the credit crunch and at the same time to increase the solidity of the banking system, might consist in a new regulation concerning the bank-firm relationship that might regard the efficiency of the system of credit worthiness assessment, with a particular focus on the probability of default (PD) of client portfolios.

This study is divided into four additional sections. Section 2 is dedicated to a review of the literature concerning the effects of the Basel II Agreement and to the predictable impact of the Basel III requirements on credit operations, as well as to the formulation of research hypotheses. Section 3 provides a description of the sample and of the methodology adopted. Section 4 shows the results of research and the last section contains the discussion of the results and conclusions.

\section{Literature Review and Research Hypotheses}

Concerns about the potential negative effects of the Basel regulation on the access to credit and on the preservation of banks solidity started in 1998, after 
the first Agreement on credit, and, in the next decades, generated a long and controversial debate among scholars. The introduction of the credit rating system occurred with the Basel II Agreement and has intensified the debate on the relationship between banks and companies, highlighting the need for banks to adopt efficient "Credit Rating System" and for business owners to change their financial conscience, paying more attention to the fulfillment of certain economic and financial equilibriums which, in the past, represented a less important variable compared to cash needs.

With the introduction of the parameters of Basel III, the literature has been enriched by scientific contributions related not only to the effects of the increased capital requirements concerning credit allocation, but also of studies concerning the impact of new liquidity requirements on credit volatility. In other words, about those fluctuations in the volume of loans that countercyclical capital buffers are deputed to correct. In this regard, there are many scholars who have come to the point of predicting a negative impact of new Basel Accords on credit allocation.

It is worth remembering that even the Basel Accord II was criticized for its potential negative effect on the allocation of credit to businesses [3].

Tanaka [4], as well as Repullo and Suarez [5], argued that the severe requirements of Basel II have been able to generate a downward trend in credit supply, particularly for certain categories of borrowers. In addition to this, the author predicted that rules of Basel II could trigger the rise of a pro-cyclical fluctuation in economy.

In general terms, the scientific literature is rather critical regarding the capability of the Basel III Accord to correct the main weaknesses of the previous agreement on credit and effectively reduce the increasing levels of illiquidity and pro-cyclicality in the banking system.

Spinassou [6], for example, argues that the new capital requirements would downsize the supply of credit without generating a considerable improvement in macroeconomic stability.

Cosimano and Hakura [7], in a study on the potential impact of the new capital requirements on credit growth, concluded that an excessively stringent regulation would cause credit rationing and, slowing global economic growth rates, would trigger a dangerous effect resulting in further damage for the entire financial industry.

Francis and Osborne [8] showed a negative trade-off between the capital requirements of Basel III and the supply of bank credit. Scholars have suggested that the effect of the Agreement would be to downsize both the amount of credit and the risk-weighted assets (RWA).

Slovik and Cournede [9] have suggested a possible direct relationship between the increase in interest rates charged by banks and the tightening of capital requirements from Basel III. In particular, the researchers argued that the Basel III requirements would result, since 2015, in an increase of interest rates applied to loans of about fifteen basis points, while, the provisions that will be effective 
since 2019, would have an even more significant negative impact.

With regard to the liquidity requirements, Cornett et al. [10] demonstrate that banks with a high level of liquid assets would continue to extend credit in the same way as they would do in the absence of the requirements imposed by Basel III parameters, while those without an adequate stock of liquid assets would have downsized their loan volumes. However, scholars argue that the new liquidity requirements will hinder the growth of supply of credit, providing, in particular, a negative impact of Liquidity Cover Ratio.

Van den End [11] conducted a simulation to assess the impact of the rules regarding the liquidity requirements in case of market shocks. The research shows that the Basel III liquidity indicators reduce the exposure to liquidity risk (inducing banks to increase the volume of high-quality liquid assets), but produce a negative impact on the supply of credit in general and, in particular, a considerable downsize of long-term issuance of debt.

King [12], in his analysis of the effects of the Net Stable Funding Ratio on spreads applied to bank loans, shows that the new liquidity requirements, linked to this indicator, can push banks to apply higher spreads to the borrowers, making less convenient the indebtedness of companies, especially when operating profitability is downsized, to face a negative leverage effect.

In Italy, studies on the impact of Basel requirements on the banking system, have focused on the efficiency of such rules in protecting the stability and liquidity of the intermediaries, ignoring its effects on the provision of credit [13] [14] [15] [16] [17]. Only a few recent studies have focused on the determinants of credit allocation. Among these we highlight the results of the analysis conducted by Burlon et al. [18] who, investigating the dynamics of credit and interest rates through inferential models, has found, on the supply side, a significant relationship between the amount of credit and some variables such as: interest rates, Tier 1, interbank debt, collateral, rating of corporate borrowers and the amount of non-performing loans. On the demand side, the authors also found significant relationships between the amount of credit and some variables such as: loan margin; cash flow/sales, trade payables/assets and firm size. In an event study conducted by Albertazzi et al. [19], has been investigated the credit crunch, also highlighted by Panetta and Signoretti [20], in the six months following the bankruptcy of Lehman Brothers Holding Inc. The results of that study showed the existence of a significant relationship between credit crunch and two key variables such as capitalization and liquidity of banks. Scholars, analyzing the characteristics of corporate borrowers, found also a decrease in lending to borrowers characterized by smaller size and greater risk.

Following the mentioned researches in the field, our study aims to investigate the negative impact of Basel pillars on credit in Italy. Focusing on the need to modify the definition of creditworthiness (PD) that represents the major obstacle, in terms of risk for banks, in granting credit on the supply side.

Consequently, the research hypotheses have been formulated as follows:

HP. 1) The requirements imposed by the Basel Accords lead to a contraction 
of credit provided to enterprises;

HP. 2) The impact of the probability of default (PD) on the amount of credit is greater than the effects of market and operational risk of banks.

\section{Materials and Methods}

The statistical analysis was conducted on a randomly selected sample of 343 Italian banks, listed and unlisted, which operated in Europe in 2014. Data gathering has been done using Bank scope (Bureau Van Dijk), Data stream (Thomson Reuters) and the annual reports of the sampled banks.

After conducting an analysis of correlation between the variables, using the Pearson index, we tested the research hypotheses through the use of multiple regression analysis (OLS).

In particular, the two research hypotheses were tested by studying the statistical significance of the following model:

$$
\begin{aligned}
\mathrm{Y}[\text { Amount of Credit }]= & \alpha+\beta_{1} \mathrm{NFSR}+\beta_{2} \mathrm{LCR}+\beta_{3} \text { Capital Requirement } \\
& +\beta_{4} \text { Leverage }+\beta_{5} \mathrm{PD}+\beta_{6} \mathrm{Size}+\beta_{7} \mathrm{VAR} \\
& +\beta_{8} \mathrm{Log} \text { OperationalRisk }+\varepsilon
\end{aligned}
$$

where:

- Amount of credit $=$ Bank loans as a percentage of total asset $(\mathrm{Y})$;

- NFSR $=$ Net Stable Funding Ratio. The NFSR is as the ratio between the available amount of stable funding and the amount required by Basel III of the same stable funding;

- $\quad$ LCR $=$ Liquidity Coverage Ratio. The LCR is defined as the ratio between stock of high quality liquid assets (HQLAs) and the total of net cash outflows in the following 30 days after an event causing financial stress;

- Capital Requirement $=$ The variable is defined as the ratio between total capital (Tier 1 and Tier 2) and the total risk weighted assets;

- Leverage $=$ The leverage ratio is defined as the ratio between Tier 1 and the sum of unweight lending risk and off-balance sheet activities;

- $\mathrm{PD}=$ Probability of default. The variable refers to the borrowers portfolios of the banks. This variable is the weighted average default probability of borrowers;

- Size $=$ This variable measures the size of banks and has been measured with the log-transformation of the total assets;

- $\mathrm{VAR}=$ Value at Risk. This variable explains the market risk. The VAR is the maximum potential loss that an activity or a portfolio of activities can suffer in a given time and at a given probability;

- Log_Operational Risk = Operational risk is the risk of loss resulting from internal factors, such as production, personnel and operating systems or from events not controlled by the bank. There are three possible approaches: Basic Indicator Approach, Standardized Approach and the Advanced Measurement Approach. Each bank chose one of these systems, which are progressively difficult to use and cost consuming. 


\section{Results}

In this section we first show the correlations observed between the variables, measured by the Pearson correlation (Table 1 ).

Before running the OLS test, we ran preliminary analysis concerning, for example, the Shapiro-Wilk test, to test the normality of residuals, the BreauschPagan test for estimating the homoskedasticity and, in the end, we made the VIF test and the tolerance test to exclude multicollinearity. Thus the result of these tests was adequate, it was possible to proceed with the OLS analysis to determine the nexus of causality between variables (Table 2 ).

The model shows an adjusted $R^{2}$ of $75.24 \%$, while the ANOVA test shows a $130.90 \mathrm{~F}$-value with a significance value greater than $99 \%$. It was found that the amount of credit was significantly dependent on two variables: the capital requirement, calculated according to the principles of Basel III (Capital Requirement), and the probability of default in banks portfolios (PD). In particular, both the regulatory capital and the probability of default have shown a negative correlation with the amount of credit extended (Regulatory capital $=-8.19 ; \mathrm{PD}=$ $-0.373)$, but certainly the former has a higher effect than the latter.

Table 1. Correlationmatrix (Pearson correlation; $\mathrm{N}=343$ ).

\begin{tabular}{|c|c|c|c|c|c|c|c|c|c|c|}
\hline & & $\begin{array}{l}\text { Amount } \\
\text { of Credit }\end{array}$ & NFSR & LCR & $\begin{array}{c}\text { Capital } \\
\text { Requirement }\end{array}$ & Leverage & PD & Size & VAR & $\begin{array}{c}\text { Log_Operational } \\
\text { Risk }\end{array}$ \\
\hline \multirow{2}{*}{ Amount of credit } & Pearson & 1 & & & & & & & & \\
\hline & Sig. & & & & & & & & & \\
\hline \multirow{2}{*}{ NSFR } & Pearson & -0.006 & 1 & & & & & & & \\
\hline & Sig. & 0.915 & & & & & & & & \\
\hline \multirow{2}{*}{ LCR } & Pearson & 0 & -0.041 & 1 & & & & & & \\
\hline & Sig. & 0.994 & 0.448 & & & & & & & \\
\hline \multirow{2}{*}{ Capital Requirement } & Pearson & -0.789 & 0.04 & -0.008 & 1 & & & & & \\
\hline & Sig. & 0 & 0.455 & 0.887 & & & & & & \\
\hline \multirow{2}{*}{ Leverage } & Pearson & 0.007 & 0.095 & -0.03 & -0.016 & 1 & & & & \\
\hline & Sig. & 0.897 & 0.08 & 0.582 & 0.767 & & & & & \\
\hline \multirow{2}{*}{ PD } & Pearson & -0.827 & 0.023 & 0.013 & 0.73 & -0.001 & 1 & & & \\
\hline & Sig. & 0 & 0.667 & 0.804 & 0 & 0.984 & & & & \\
\hline \multirow{2}{*}{ Size } & Pearson & 0.055 & 0.028 & -0.018 & -0.074 & 0.068 & -0.067 & 1 & & \\
\hline & Sig. & 0.311 & 0.608 & 0.747 & 0.173 & 0.209 & 0.215 & & & \\
\hline \multirow{2}{*}{ Var } & Pearson & -0.021 & 0.1 & -0.143 & 0.047 & -0.036 & -0.3 & 0.044 & 1 & \\
\hline & Sig. & 0.692 & 0.064 & 0.008 & 0.384 & 0.509 & 0.58 & 0.421 & & \\
\hline \multirow{2}{*}{ Log_OperationalRisk } & Pearson & -0.011 & -0.052 & -0.096 & 0.034 & 0.004 & 0.009 & 0.057 & 0.04 & 1 \\
\hline & Sig. & 0.842 & 0.34 & 0.076 & 0.535 & 0.94 & 0.864 & 0.289 & 0.457 & \\
\hline
\end{tabular}

Source: Author's calculation on data collected from Data Stream. 
Table 2. Regressionanalysis (OLS).

\begin{tabular}{|c|c|c|}
\hline \multirow{2}{*}{ Model } & \multicolumn{2}{|c|}{ Amount of Credit } \\
\hline & Standardized coefficients & T-statistics \\
\hline NFSR & 0.003 & 0.96 \\
\hline LCR & 0.003 & 0.13 \\
\hline Capital Requirement & $-8.19^{\star}$ & -9.99 \\
\hline Leverage & -0.002 & -0.09 \\
\hline $\mathrm{PD}$ & $-0.373^{*}$ & -13.63 \\
\hline Size & -0.006 & -0.40 \\
\hline VAR & -0.020 & -0.77 \\
\hline Log_Operational Risk & 0.010 & 0.039 \\
\hline \multirow{2}{*}{ Model summary } & R-Square & Adjusted R-Square \\
\hline & 0.7582 & 0.7524 \\
\hline \multirow{2}{*}{ ANOVA } & \multicolumn{2}{|c|}{$\mathrm{F}$} \\
\hline & \multicolumn{2}{|c|}{$130.90^{*}$} \\
\hline
\end{tabular}

Source: Author's calculation on data collected from Data Stream.

These results allow us to provide the following answers to the research questions.

Given the significance of only two representative variables of the pillars of Basel, it can be concluded that the first hypothesis (Hp. 1) can be only partially confirmed. Indeed, although the capital requirements and the probability of default are negatively correlated to the credit amount, we didn't find any significance of other parameters. In particular, compared to the first research hypothesis, the results show that the LCR and NSFR indicators, as well as the leverage and the variables representing the banking risk, have no significant impact on the amount of credit extended by banks.

The second hypothesis (HP. 2) is however confirmed from the regression analysis. It shows that the credit risk, measured by the probability of default, has a negative impact on the amount of credit, while other components of risk, particularly the market risk and the operational one, don't significantly affect the credit amount.

\section{Discussion and Conclusions}

In recent years, the strength of the Italian banking system has deteriorated due to increased non-performing loans (NPL). This phenomenon is caused by the continuing economic crisis, which makes the debt service increasingly difficult, particularly for small and medium enterprises.

The progressive deterioration of the credit market in Italy and Europe leaded the European Central Bank to extraordinary measures (Quantitative Easing) with the purpose to foster credit allocation by banks. However, in Italy, results 
seem not encouraging.

This already difficult context has to face also the progressive implementation of Basel III, which was implemented because of the crisis of 2007 and was an elaborate reform with the objective of strengthening the adjustment procedures, control and management of the banking industry.

Therefore, this Agreement should contribute to improve efficiency in reduce the risks of the financial market and to increase the financial information of credit institutions [21].

However, in contradiction of these expectations, this research shows, at least in Italy, some critical side connected to the Agreements on credit.

It seems that the increase in capital requirements and the customer portfolio quality leads to a significant reduction of loans. In Italy the need to increase the capital and at the same time, the requirements need to reduce exposure to risk (probability of default), could induce banks to divest from companies and to increase investment in government bonds. The result of such a mechanism could therefore be an excess of demand of the mentioned titles that would result in a decline in yields that could have adverse effects on the income statements of banks.

Therefore, the Basel Accord increases capitalization and adversity to the risk of the credit system to a level that would result in the phenomena of credit crunch. This can generate at least two effects, both configurable as adverse selection mechanisms. On one hand, the Agreement could further reduce the profitability of banks that are forced to finance the safest companies, but at very low rates; on the other hand, it could improve the credit allocation among companies that have not particularly innovative investments to be proposed but are more capable to guarantee the debt service.

These statements are confirmed by the current debate concerning the credit risk models of the new Basel Capital Accord IV. In particular, within the Basel Committee and the International Conference of Banking Supervisors (ICBS) there are two different orientations. An Anglo-Saxon point of view which would prefer the exclusive use of standard systems for credit risk assessment, and another point of view which would prefer to maintain the possibility for banks to use internal rating models (IRB).

The exclusive use of standard systems would cause, for banks that adopt internal systems, a considerable increase in capital requirements, especially in those regions, such as Italy, where the crisis has generated an increase in nonperforming loans.

The overall effect would be to hinder overall economic growth and undermine the prospects for a successful implementation of the objectives pursued through the quantitative easing by the European Central Bank.

The Basel Committee and the supervisory authorities, should therefore commit themselves not so much to increase the capital requirements, but to implement new models to ensure a better balance between regulatory capital and credit risk taken by the bank, but also considering the need not to penalize the 
amount of credit allocated. To this end, it is necessary to adopt models that consider the peculiarities of the production system to which they relate. Although the economy is now globalized, there are still significant differences between the production systems of the various countries that cannot be ignored by the agreements on credit in the name of standardization of the measurement processes that has no rationality, but to reduce the banks' monitoring costs.

This research has highlighted the importance of two critical variables (capital requirement and probability of default of borrowers) which, if exacerbated, can penalize the amount of credit allocated in Italy, as already demonstrated in wider economic systems [22]. Therefore, new lending models should pay special attention to the combined effect of these two elements.

However, these results, taking in to account the mentioned differences between economic systems, cannot be generalized to other individual countries, which could be the subject of further future research. Furthermore it appears necessary to study the determinants of credit in relation not only to the characteristics of the supply, but also to the once concerning the demand.

\section{References}

[1] Bank of International Settlements (2011) Basel Committee on Banking Supervision -Basel III: A Global Regulatory Framework for More Resilient Banks and Banking System. Bank of International Settlements Communication, 6, 1-69.

[2] Stiglitz, J. and Weiss, A. (1981) Credit Rationing in Markets with Imperfect Information. American Economic Review, 71, 393-410.

[3] Mustilli, M., Gangi, F. and Campanella, F. (2008) Credit Supply, Allocation Efficiency and Firms' Growth Potential: An Empirical Analysis. Rassegna Economica, 1, 5-35.

[4] Tanaka, M. (2003) The Macroeconomic Implications of the New Basel Accord. CESifo Economic Studies, 49, 217-232. https://doi.org/10.1093/cesifo/49.2.217

[5] Repullo, R. and Suarez, J. (2004) Loan Pricing under Basel Capital Requirements. Journal of Financial Intermediation, 13, 496-521.

[6] Spinassou, K. (2013) Basel III Capital Requirements and Regulatory Power: The Impact on Bank Risk-Taking and Credit Supply. SSRN Working Paper, No. 2307721, $1-27$.

[7] Cosimano, T.F. and Hakura, D. (2011) Bank Behavior in Response to Basel III: A Cross-Country Analysis. International Monetary Fund Working Paper, 119, 1-34.

[8] Francis, W. and Osborne, M. (2009) Bank Regulation, Capital and Credit Supply: Measuring the Impact of Prudential Standards. UK Financial Services Authority Occasional Paper, 36, 1-41.

[9] Slovik, P. and Cournède, B. (2011) Macroeconomic Impact of Basel III. OECD Economics Department Working Papers, 844, 1-15.

[10] Cornett, M., McNutt, J., Strahan, P. and Tehranian, H. (2011) Liquidity Risk Management and Credit Supply in the Financial Crisis. Journal of Financial Economics, 101, 297-312.

[11] Van den End, J.W. (2012) Liquidity Stress-Tester: Do Basel III and Unconventional Monetary Policy Work? Applied Financial Economics, 22, 1233-1257. https://doi.org/10.1080/09603107.2011.646065

[12] King, M.R. (2013) The Basel III Net Stable Funding Ratio and Bank Net Interest 
Margins. Journal of Banking \& Finance, 37, 4144-4156.

[13] D’Ippoliti, C. and Roncaglia, A. (2011) Italy: A Crisis in the Crisis. Moneta e Credito, 64, 189-227.

[14] Fratianni, M. and Marchionne, F. (2010) The Banking Bailout of the Subprime Crisis: Size and Effects. PSL Quarterly Review, 63, 187-233.

[15] Masera, R. (2010) Reforming Financial Systems after the Crisis: A Comparison of EU and USA. PSL Quarterly Review, 63, 299-362.

[16] Montanaro, E. and Tonveronachi, M. (2011) A Critical Assessment of the European Approach to Financial Reforms. PSL Quarterly Review, 64, 193-226.

[17] Erzegovesi, L. (2015) The Securitization Framework of Basel III and Government Guarantees on SMEs Loans Portfolios. Department of Economics and Management Univeristy of Trento Discussion Papers, 12, 1-45.

[18] Burlon, L., Fantino, D., Nobili, A. and Sene, G. (2016) The Quantity of Corporate Credit Rationing with Matched Bank-Firm Data. Banca d'Italia Working Papers, No. 1058, 1-81.

[19] Albertazzi, U. and Marchetti, D.J. (2010) Credit Supply, Flight to Quality and Evergreening: An Analysis of Bank-Firm Relationships after Lehman. Banca d Italia Working Papers, No. 756, 1-59.

[20] Panetta, F. and Signoretti, F.M. (2010) Supply and Demand of Credit in Italy during the Financial Crisis. Banca d Italia Occasional Paper, 63, 1-43.

[21] Campanella, F., Del Giudice, M. and Della Peruta, M.R. (2013) The Role of Information in the Credit Relationship. Journal of Innovation and Entrepreneurship, 2, 17. https://doi.org/10.1186/2192-5372-2-17

[22] Campanella, F., Mustilli, M. and D’Angelo, E. (2017) Basel III and Credit Crunch: an Empirical Test with Focus on Europe. Journal of Applied Finance and Banking, forthcoming.

\section{Submit or recommend next manuscript to SCIRP and we will provide best service for you:}

Accepting pre-submission inquiries through Email, Facebook, LinkedIn, Twitter, etc. A wide selection of journals (inclusive of 9 subjects, more than 200 journals) Providing 24-hour high-quality service User-friendly online submission system Fair and swift peer-review system Efficient typesetting and proofreading procedure Display of the result of downloads and visits, as well as the number of cited articles Maximum dissemination of your research work

Submit your manuscript at: http://papersubmission.scirp.org/ Or contact ajibm@scirp.org 